\title{
IMPROVED MICROMORPH TANDEM CELL PERFORMANCE THROUGH ENHANCED TOP CELL CURRENTS
}

\author{
Rainer Platz*, N. Pellaton Vaucher, D. Fischer, J. Meier and A. Shah \\ Institut de Microtechnique, Université de Neuchâtel, 2000 Neuchâtel, Switzerland \\ *present address: Department of Electrical Engineering, Princeton University, Princeton NJ 08544, USA \\ E-Mail: rplatz@ee.princeton.edu http://www.princeton.edu/ rplatz/
}

\begin{abstract}
Two approaches to increasing the current in the amorphous silicon top cell of an amorphous silicon/ microcrystalline silicon (a-Si:H/ $/ \mathrm{c}-\mathrm{Si}: \mathrm{H})$ tandem cell are presented. Our goal is to raise the stabilized efficiency of such cells.

The deposition of the amorphous top cell at higher than standard substrate temperature is shown to reduce the optical gap of the i-layer and to increase the current which is generated with a given i-layer thickness.

Furthermore, a selectively reflecting $\mathrm{ZnO}$ interface layer between the component cells is presented as a viable tool for enhancing the current generation in the top cell by selective reflection of light.

We present a micromorph tandem cell containing the amorphous top cell deposited at high substrate temperature, and additionally the $\mathrm{ZnO}$ mirror layer. A top cell thickness of $150 \mathrm{~nm}$ is shown to be sufficient to provide a current density of $13 \mathrm{~mA} / \mathrm{cm}^{2}$ in the top cell.

Finally, the influence of such thin top cells on the stabilized efficiency of the tandem cell is investigated by experiment and by means of semi-empirical modeling. Model and experiment confirm that such reduced-gap top cells, together with current enhancement due to the mirror layer, have a high potential for improving the stabilized efficiency of micromorph tandem cells.
\end{abstract}

\section{Introduction}

Micromorph cells, i.e. amorphous silicon/ microcrystalline silicon (a-Si:H/ $/ \mathrm{c}-\mathrm{Si}: \mathrm{H}$ ) tandem cells, are continuously gaining in interest as promising thin-film silicon solar cells. $10.7 \%$ stabilized efficiency has been achieved so far [1] (as confirmed by the Fraunhofer Institut für Solare Energiesysteme, Freiburg/Germany).

There is potential for a further increase of the stabilized efficiency for such micromorph tandem cells both from the $\mu \mathrm{c}-\mathrm{Si}: \mathrm{H}$ and from the a-Si:H cell point of view. In order to raise the efficiency, the basic problem of combining a high-current but low-voltage $\mu \mathrm{c}-\mathrm{Si}: \mathrm{H}$ bottom cell with a low-current but high-voltage a-Si:H top cell must be resolved. In this paper, we focus on the optimization of the a-Si:H top cell with respect to this problem.

As a microcrystalline $p-i-n$ cell can provide a current of at least $26 \mathrm{~mA} / \mathrm{cm}^{2}$, the top cell should generate at least $13 \mathrm{~mA} / \mathrm{cm}^{2}$ in order to obtain current matching conditions.
The difficult task is hereby to combine the required current generation with the best possible stability. We have previously shown [2], that an a-Si:H top cell with an optical gap slightly lower than for standard a-Si:H material would yield micromorph tandem cells with increased stabilized efficiency. Additionally, other concepts such as selectively reflecting interface layers between the top and the bottom cell can contribute to higher stabilized efficiencies [3].

In this work, we present results on a-Si:H cells deposited at high substrate temperatures where the current generation is enhanced due to a reduced optical gap of the i-layer. These cells are inserted as top cells into micromorph tandem cells. Finally, we combine these reduced-gap top cells with a selectively reflecting $\mathrm{ZnO}$ interface layer for a further increase in current.

\section{Top cells with high-temperature i-layers}

We deposited a series of intrinsic a-Si:H layers at different substrate temperatures using the Very High Frequency Glow Discharge (VHF-GD) technique at $70 \mathrm{MHz}$. The optical gap of the material decreases for increasing substrate temperature during deposition. Fig.1. shows the absorption coefficient $\alpha$ for three different substrate temperatures as determined by Photothermal Deflection Spectroscopy (PDS) and transmission/reflection measurements. There is an almost parallel shift of the absorption spectrum towards lower energies with increasing substrate temperature. The decrease of the optical gap correlates with a decrease of the hydrogen content in the films from 9at. $\%$ at $220^{\circ} \mathrm{C}$ to 6 at. $\%$ at $330^{\circ} \mathrm{C}$ (not shown).

We incorporated these high temperature materials as the absorbing layers in single-junction $p$-i-n cells. The doped layers ( $p$ - as well as n-type) were deposited at $270^{\circ} \mathrm{C}$ (standard substrate temperature).

The reduced optical gap of i-layer material deposited at high substrate temperatures results in an enhancement of the spectral response (SR) for red light when this material is inserted as the i-layer into a $\mathrm{p}$-i-n cell. Fig.2. shows SR curves (measured under short circuit conditions) for two single-junction $p-i-n$ cells deposited at substrate temperatures of $300^{\circ} \mathrm{C}$ and $330^{\circ} \mathrm{C}$ normalized to the SR of a "standard" $p$-i-n cell at $270^{\circ} \mathrm{C}$. One clearly observes an increase of the SR in the long wavelength-region due to the increased absorption coefficient (Fig.1.) of the i-layer material deposited at high temperature. At $700 \mathrm{~nm}$, the 
spectral response is increased by $20 \%$ for the $330^{\circ} \mathrm{C}$ cell as compared to the "standard" $270^{\circ} \mathrm{C}$ cell.

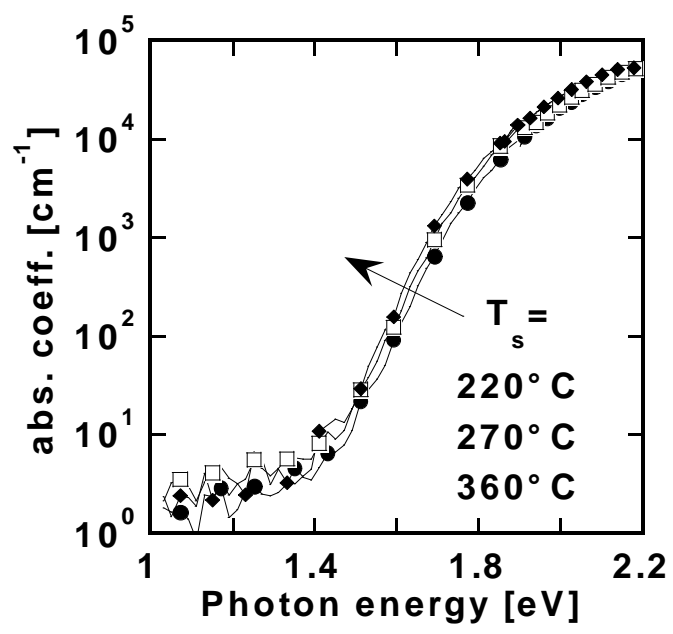

Fig.1.: Absorption coefficient $\alpha$ for a-Si:H films deposited from $\mathrm{SiH}_{4}$ (no $\mathrm{H}_{2}$-dilution) at different substrate temperatures as determined from PDS and transmission/reflection measurements.

The incorporation of such high-temperature i-layers into $p-i-n$ solar cells is usually found to degrade the cell performance, i.e. mainly $\mathrm{V}_{\mathrm{oc}}$ and $\mathrm{FF}$ [4]. In our case also, the $\mathrm{SR}$ in the blue wavelength region (Fig.2.) is reduced due to boron contamination of the i-layer when depositing the i-layer at increased substrate temperature. This reduces the $\mathrm{FF}$ and $\mathrm{V}_{\text {oc }}$ values for those cells.

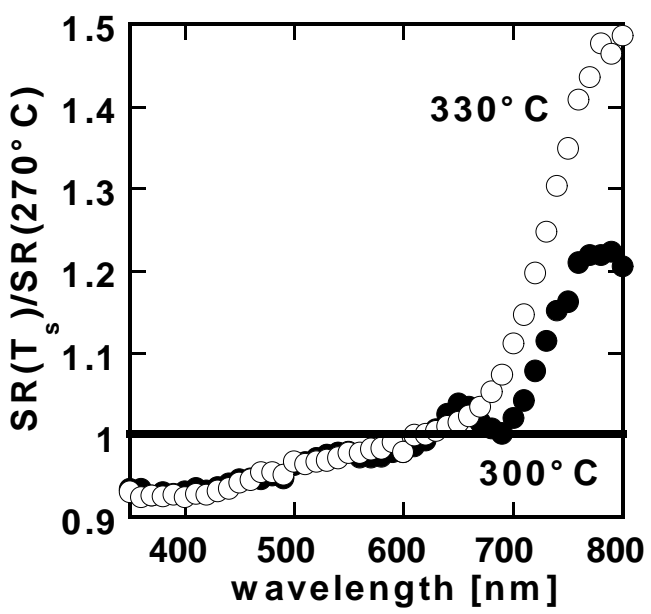

Fig.2.: Spectral response curves (at OV bias) for 300nm thick single-junction $\mathrm{p}$-i-n cells with $\mathrm{i}$-layers deposited at 300 and $330^{\circ} \mathrm{C}$ from undiluted silane normalized to the $\mathrm{SR}(\mathrm{OV})$ of a cell deposited at $270^{\circ} \mathrm{C}$. In order to exclude experimental variation due to the reflectivity of the back contact, all 3 samples were contacted in the same run with silver contacts.

We therefore developed amorphous p/IL-i-n cells containing i-layer material deposited at higher than standard substrate temperature [5] showing good $\mathrm{V}_{\text {oc }}$ and FF values due to an optimized p-i-interface layer (IL). $V_{o c}$ values as high as $820 \mathrm{mV}$ and fill factors of over $70 \%$ could be obtained for i-layer deposition temperatures of up to $330^{\circ} \mathrm{C}$ when employing this interface layer. This interface layer also avoids losses in current due to a reduced SR in the blue wavelength region (Fig.3.).

The increase in current due to the reduced optical gap of the i-layer is even more pronounced when such cells are employed as top cells in micromorph tandem cells. Fig.3. shows the SR curves for top cells of micromorph tandem cells where the top cell i-layer has been deposited at three different substrate temperatures. The current increases from $11.9 \mathrm{~mA} / \mathrm{cm}^{2}\left(220^{\circ} \mathrm{C}\right)$ to $12.2 \mathrm{~mA} / \mathrm{cm}^{2}$ $\left(270^{\circ} \mathrm{C}\right)$ and is $13.1 \mathrm{~mA} / \mathrm{cm}^{2}$ at $330^{\circ} \mathrm{C}$, see also Fig.6.

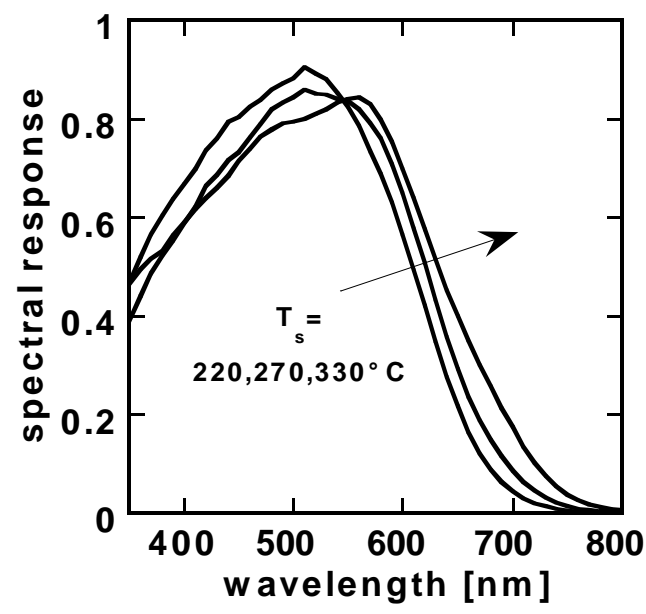

Fig.3.: Influence of the substrate temperature on the top cell spectral response $\left(d_{i}=300 \mathrm{~nm}\right)$ in the micromorph configuration. $270^{\circ} \mathrm{C}$ is our standard temperature, the cell at $220^{\circ} \mathrm{C}$ is deposited using $\mathrm{H}_{3}$-dilution. The cell at $330^{\circ} \mathrm{C}$ contains an optimized $\mathrm{p} / \mathrm{i}$ interface layer.

\section{ZnO intermediate layer}

As a second means to enhance the current generation in the amorphous top cell, a $\mathrm{ZnO}$ intermediate reflector layer was inserted in between the top and bottom cell (Fig.4.). Such a layer [3] acts as a wavelength-selective mirror due to positive and negative interference if its thickness is properly adjusted. In the case of micromorph tandem cells, it should reflect green and partially red light, which has not been absorbed in the first pass, back into the top cell whereas infrared light should be transmitted directly into the microcrystalline bottom cell. This bears the possibility to enhance the top cell current density or, alternatively, to generate the same current density within a thinner top cell. Fig.5. shows the influence of such a $\mathrm{ZnO}$ reflective layer on the top cell spectral response in a micromorph tandem cell. Most encouraging is the fact that our experimental results show for optimally tuned $\mathrm{ZnO}$ layers almost negligible losses in the total (i.e. top + bottom cell) current $[3,6]$. 


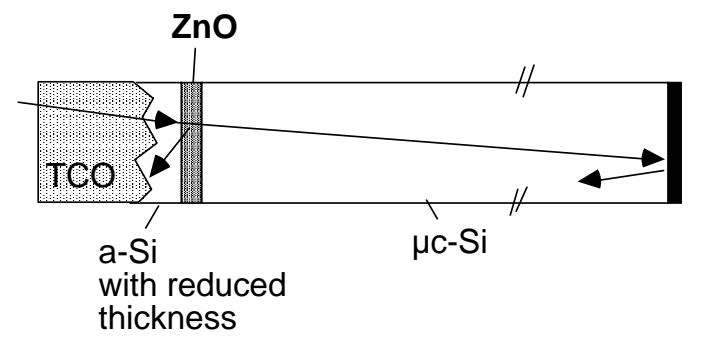

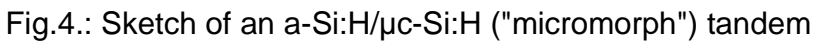
cell with a $\mathrm{ZnO}$ selectively reflecting layer between top and bottom cell.

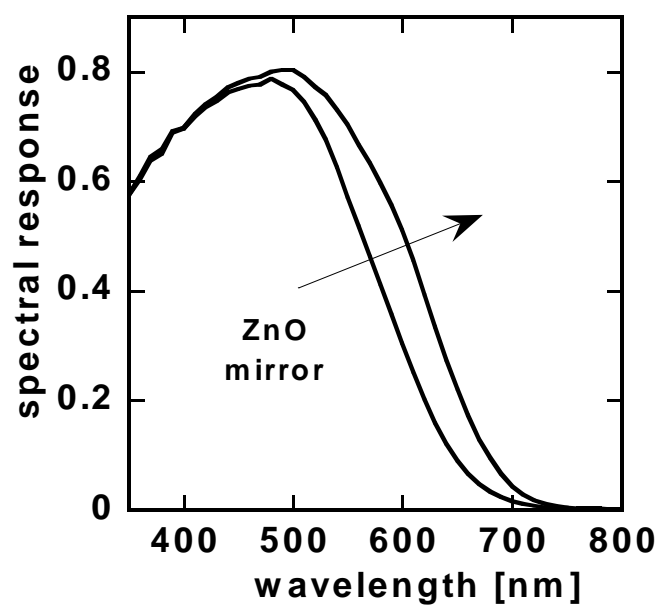

Fig.5.: Influence of a $\mathrm{ZnO}$ inner mirror on top cell spectral response $\left(d_{1}=150 \mathrm{~nm}\right)$. Both top cells are deposited at $220^{\circ} \mathrm{C}$ employing $\mathrm{H}_{2}$-dilution for the i-layer.

\section{Top cell current enhancement}

Finally, we incorporated these high-Ts $p / I L-i-n$ cells as top cells in micromorph tandem cells. Fig.6. shows current densities of such micromorph top cells deposited at $330^{\circ} \mathrm{C}$ (•) in comparison to "standard" top cells, deposited at $270^{\circ} \mathrm{C}(\boldsymbol{\theta})$, and for different top cell i-layer thicknesses in the initial state. The gain in current for a given i-layer thickness is on the order of $0.8 \mathrm{~mA} / \mathrm{cm}^{2}$ when going from "standard" temperature top cells to high-temperature p/IL-i-n top cells.

A top cell current of $13 \mathrm{~mA} / \mathrm{cm}^{2}$, as would be necessary to match a total cell current of $26 \mathrm{~mA} / \mathrm{cm}^{2}$, is available with a high- $T_{s}$ top cell of about $250 \mathrm{~nm}$ thickness, whereas one needs a "standard" temperature top cell of around 400nm thickness in order to obtain this current (Fig.6.).

Also shown in Fig.6. are examples of cells containing $\mathrm{ZnO}$ selectively reflecting mirror layers (open symbols). The increase in current density due to the $\mathrm{ZnO}$ layer is on the order of $10 \%$ for both deposition temperatures. A cell with a $\mathrm{ZnO}$ reflecting layer generates with roughly $2 / 3$ of the i-layer thickness the same current as a cell without reflecting layer.

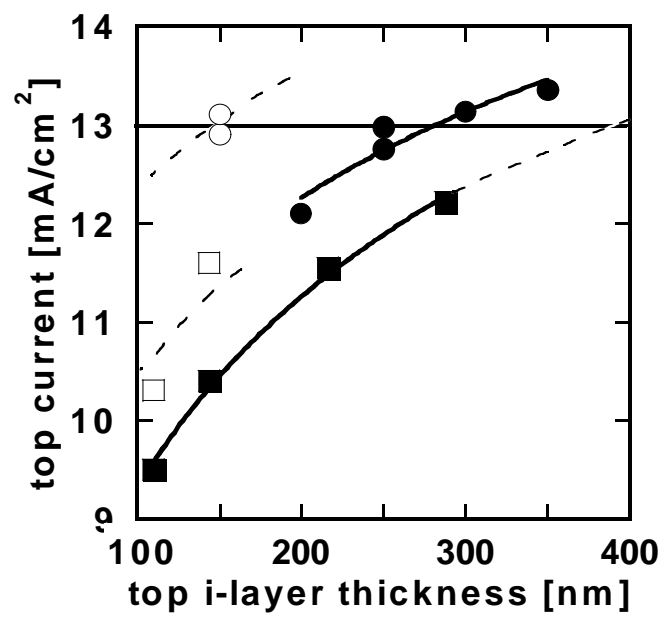

Figure 6: Experimental current densities determined from spectral response measurements as a function of the cell thickness for standard-temperature $\left(270^{\circ} \mathrm{C}\right)(\boldsymbol{\sigma})$ and high$\mathrm{T}_{\mathrm{s}}\left(330^{\circ} \mathrm{C}\right) \mathrm{p} / \mathrm{IL}-\mathrm{i}-\mathrm{n}(\bullet)$ cells. Furthermore, values for cells incorporating a selectively reflecting $\mathrm{ZnO}$ layer with standard-temperature cells $(\square)$ and high- $\mathrm{T}_{\mathrm{s}} \mathrm{p} / \mathrm{IL}-\mathrm{i}-\mathrm{n}$ cells (O) are plotted. The target value is $13 \mathrm{~mA} / \mathrm{cm}^{2}$ supposing that the microcrystalline bottom cell can provide $26 \mathrm{~mA} / \mathrm{cm}^{2}$.

The combination of a high-temperature amorphous top cell with a selectively reflecting $\mathrm{ZnO}$ layer allows for a current density as high as $13 \mathrm{~mA} / \mathrm{cm}^{2}$ in the top cell with only 150nm i-layer thickness, as is demonstrated in Fig.6. Thus, an only $150 \mathrm{~nm}$ thick amorphous cell can match the current density of a micromorph tandem cell with a total available current of $26 \mathrm{~mA} / \mathrm{cm}^{2}$ while a conventional amorphous top cell needs more than the double thickness.

Due to the connection between thickness and stability of an amorphous cell, such thin amorphous top cells can be expected to show improved stability as compared to standard top cells providing the same current densities. This issue is addressed in the following section.

\section{Effect on stability}

Semi-empirical modeling [2] allows us to predict the influence of the $\mathrm{ZnO}$ intermediate layer and hightemperature top cells on the stabilized tandem cell efficiency (Fig.7.). We assumed for the high-T $\mathrm{p} / \mathrm{IL}-\mathrm{i}-\mathrm{n}$ cell at $330^{\circ} \mathrm{C}$ the experimental value for the stabilized $\mathrm{V}_{\text {oc }}$ of $0.78 \mathrm{~V}$ and in a first approximation the same FF as a function of the i-layer thickness as for the standard cells which has shown to be a reasonable assumption. The modeling procedure is described in more detail in [2]. Fig.7. shows that the high- $T_{s}$ p/IL-i-n cell is expected to yield a slightly higher stabilized efficiency in a micromorph tandem cell than a "standard" cell, in spite of its $\mathrm{V}_{\text {oc }}$ which is $0.06 \mathrm{~V}$ lower than that of the "standard" cell. Insertion of a selectively reflecting $\mathrm{ZnO}$ layer results for both top cell types in a remarkable increase of the stabilized efficiency and a shift of the optimum top cell thickness to smaller values as higher current density values are obtained with thinner cells. Fig.7. shows furthermore that a combination 
of a high-current top cell with a $\mathrm{ZnO}$ interface layer has the highest potential to improve the stabilized efficiency of micromorph tandem cells. The optimum of the stabilized efficiency appears for very thin top cells, i.e. around $150 \mathrm{~nm}$ i-layer thickness and current values close to matching conditions.

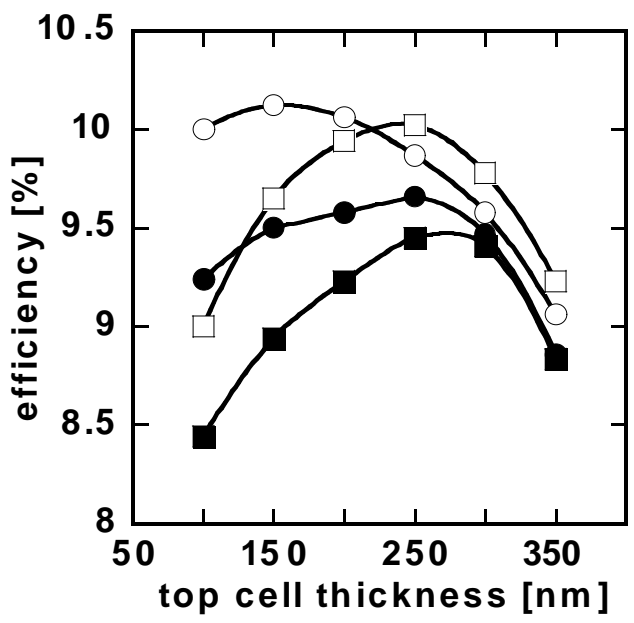

Fig.7.: Modeled tandem cell efficiencies (degraded state) as a function of the top cell thickness for standard ( $\boldsymbol{\square})$ and high-temperature $(\bullet)$ top cells, with (open symbols) and without (black symbols) a $\mathrm{ZnO}$ reflecting layer.

Preliminary experimental evidence for the high potential to increase the stabilized efficiency of micromorph tandem cells containing such high-current top cells together with a $\mathrm{ZnO}$ reflector layer is given by the following result: after $1200 \mathrm{~h}$ of light-soaking $\left(50^{\circ} \mathrm{C}\right.$, $100 \mathrm{~mW} / \mathrm{cm}^{2}$, spectrum close to AM1.5), a micromorph tandem cell containing a $150 \mathrm{~nm}$ thick high- $\mathrm{T}_{\mathrm{s}}\left(330^{\circ} \mathrm{C}\right)$ top cell and additionally a $\mathrm{ZnO}$ intermediate layer showed the following performance: $\quad V_{o c}=1.21 \mathrm{~V}, \quad F F=69.3 \%$, $I_{\text {sctop }}=13.1 \mathrm{~mA} / \mathrm{cm}^{2}, I_{\text {sc. bottom }}=11.2 \mathrm{~mA} / \mathrm{cm}^{2}$. It is important to note that a current of more than $13 \mathrm{~mA} / \mathrm{cm}^{2}$ can be obtained after stabilization with such a thin amorphous top cell. The FF of the tandem cell may be somewhat misleading due to the current mismatch. For a tandem cell closer to matching conditions, it can be expected to be slightly lower [7].

\section{Conclusions}

We have demonstrated two methods to enhance the current density in the top cell of micromorph tandem cells. The deposition of the amorphous top cell i-layer in a micromorph tandem cell at high substrate temperature reduces the optical gap and increases thereby the current generation for a given i-layer thickness. The detrimental effects of the i-layer deposition at increased temperature can be counteracted by the insertion of an interface layer at the $\mathrm{p} / \mathrm{i}$-interface.

A selectively reflecting $\mathrm{ZnO}$ interface layer inserted between the both component cells further enhances the current density in the amorphous top cell.
The combination of both measures yields a micromorph top cell which generates with only $150 \mathrm{~nm}$ ilayer thickness a current density of $13 \mathrm{~mA} / \mathrm{cm}^{2}$. This means a reduction to less than $50 \%$ of the necessary thickness for a "standard" top cell.

Such thin amorphous top cells can be expected to show enhanced stability against light-soaking which is confirmed by preliminary experimental results.

\section{Acknowledgements}

Financial support by Swiss Federal Department of Energy BEW/OFEN under grant 19431 is gratefully acknowledged. R. Platz thanks the Arthur u. Aenne Feindt Stiftung, Hamburg (Germany), the Fondation CharlesEdouard Guillaume, Bienne (Switzerland), and EPRI for financing his stay at Princeton University.

\section{References}

J. Meier, S. Dubail, R. Platz, P. Torres, U. Kroll, J.A. Anna Selvan, N. Pellaton Vaucher, C. Hof, D. Fischer, H. Keppner, R. Flückiger, A. Shah, V. Shklover, K.-D. Ufert, Proc. PVSEC-9, Miyazaki 1996, to be published.

2 R. Platz, J. Meier, D. Fischer, S. Dubail and A. Shah, MRS Symp. Proc. 467 (1997), to be published.

3 D. Fischer, S. Dubail, J.A. Anna Selvan, N. Pellaton Vaucher, R. Platz, C. Hof, U. Kroll, J. Meier, P. Torres, H. Keppner, M. Götz, A. Shah, K.-D. Ufert, Proc. 25th IEEE PVSC (1996) 1053.

$4 \quad$ M. Nishikuni, T. Takahama, S. Okamoto, K. Ninomiya, H. Nishiwaki, S. Tsuda, A. Takeoka, M. Ohnishi, S. Nakano and Y. Kuwano, Progress in Photovoltaics 2 (1994) 211.

$5 \quad$ R. Platz et al., to be published.

6 D. Fischer, H. Keppner, U. Kroll, P. Torres, J. Meier, R. Platz, S. Dubail, J.A. Anna Selvan, N. Pellaton Vaucher, Y. Ziegler, R. Tscharner, C. Hof, N. Beck, M. Goetz, P. Pernet, M. Goerlitzer, N. Wyrsch, J. Vuille, J. Cuperus and A. Shah, Proc. 14th EC PVSEC, Barcelona 1997, to be published. Energy Materials and Solar Cells 46 (1997) 157. 